\title{
Histological Description of the Skin Glands of Phyllobates bicolor (Anura: Dendrobatidae) Using Three Staining Techniques
}

\author{
Descripción Histológica de las Glándulas Cutáneas de Phyllobates bicolor \\ (Anura: Dendrobatidae) Usando Tres Técnicas de Tinción
}

\author{
Freddy Moreno-Gómez; Tania Duque*; Leonardo Fierro"*; Juan Arango ${ }^{* * * *}$; \\ Xiomara Peckham ${ }^{* * * * *}$ \& Helberg Asencio-Santofimio**
}

MORENO-GÓMEZ, F.; DUQUE, T.; FIERRO, L.; ARANGO, J.; PECKHAM, X. \& ASENCIO-SANTOFIMIO, H. Histological description of the skin glands of Phyllobates bicolor (Anura: Dendrobatidae) using three staining techniques. Int. J. Morphol., 32(3):882$888,2014$.

SUMMARY: The mechanisms to obtain and store skin toxins in frogs in of the family Dendrobatidae are not completely understood. In order to contribute to understand how toxins are stored, we provide a histological description of the cutaneous glands of the species Phyllobates bicolor. The skin of two adult frogs was examined through three histological staining techniques (hematoxilin-eosin, PAS and Masson Trichrome) using conventional optic microscopy. The skin of Phyllobates bicolor contains two types of exocrine glands: mucous and serous, which empty their products to the epidermal surface through an intra-epithelial duct that leads to a stoma. The mucous and serous glands and the intercalated ducts are surrounded by a discontinuous sheath of myoepithelial cells, which colapse the lumen of the acinus and the lumen of ducts and facilitate the secretion and release of their content. The serous glands have a polarized syncytium of tall cuboidal or columnar epithelial cells. Both glands have a mixed secretion, thus, the contents of mucous glands tend to be neutral and basophilic, while the contents of the serous glands are basophilic and acidophilic.

KEY WORDS: Amphibians; Phyllobates bicolor; Integument; Epidermis; Dermis; Mucous glands; Serous glands; Chemical defenses; Bioaccumulation.

\section{INTRODUCTION}

The skin of amphibians contains a large number of chemical compounds, which may play an important role as a defense mechanism against potential predators and as a protection against ectoparasites (Daly et al., 2005). These compounds can be produced de novo (Schöpf, 1961; Daly, 1995; Smith et al., 2002) or obtained from an external source as it has been suggested for amphibians of the Dendrobatidae family (Daly; Saporito et al., 2009, 2012), which store the compounds that they obtain in cutaneous glands located throughout the skin.

Histologically the skin of frogs consists of an epidermis and dermis. Depending on the species, the epidermis of frogs can be a mucous stratified squamous epithelium (non keratinized) 6-8 $\mathrm{mm}$ thick, that consists of three strata of keratinocytes (basale, intermediate and apical) or stratified squamous epithelium (keratinized) that also consists of three strata of keratinocytes (basal, intermediary and cornified). The stratum basale consists of a monolayer of tall cuboidal cells, the intermediate stratum consists of 2 to 3 layers of polygonal cells and the stratum corneum consists of a layer of cells with no nuclei filled with keratin (Felsemburgh $e t$ al., 2007). The dermis, consists of two strata, the stratum spongiosum below the epidermis that contains loose connective tissue, melanin pigment cells (chromophores), blood vessels, mucous and serous glands, and a compact stratum of dense irregular connective tissue that is rich in criss-crossed collagen fibers (Felsemburgh et al.; Delfino et al., 2010). The cutaneous glands of amphibians generally correspond to four types depending on their secretion: mucous glands, serous glands, mixed (seromucous) and sebaceous; however the mucous and serous (granular) glands are the glands that have been described in the majority of studies. These glands are described histologically as

\footnotetext{
* Pontificia Universidad Javeriana Cali, Grupo de Investigación en Ciencias Básicas y Clínicas, Depto. de Ciencias Básicas de la Salud, Cali, Colombia. ** Universidad del Valle, Escuela de Ciencias Básicas de la Salud, Cali, Colombia.

**** Universidad de Caldas, Departamento de Biología, Manizales, Colombia.

${ }^{* * * * *}$ Long Island University, Biology Department, New York, USA.
} 
accessory cutaneous structures and are found interspersed throughout the skin in different species of frogs (Neuwirth et al., 1979). In specialized literature the mucous glands are described as epithelial units (adenomeres or acini) with narrow lumens that consist of a single layer of secretory cells (Angel et al., 2003; Delfino et al.). They consist of two types of cells that can be distinguished with transmission electron microscopy because of the presence of secretory granules. One group consists of cells called principal cells, which are characterized by small secretory granules, and the other groups consists of intercalated cells found in between the principal cells with secretory granules that are bigger, but are less abundant (Els \& Henneberg, 1990). The serous glands are described as a glandular compartment with a wide lumen that contains a glandular unit as a polarized syncytium of secretory cells. In their cytoplasm it is possible to see the basic organization of the steroid and protein secreting cells, such as numerous mitochondria, Golgi complex and endoplasmic reticula, associated to a large number of cytoplasmic granules with secretory vesicles inside, as multivesicular bodies (Neuwirth et al.; Angel et al.). These glands are responsible for skin homeostasis and chemical defense against predators (due to their alkaloid content) y against bacteria (due to the content of antimicrobial peptides), all of which are contained within secretory granules that accumulate in the cytoplasm (Delfino et al.).

There are few histological descriptions in the literature of the cutaneous glands of the different species of frogs. The majority of histological studies have been performed in European species. The purpose of our study is a histological description, using three staining techniques (hematoxiline-eosin, PAS and Masson Trichrome) using conventional optic microscopy, of the mucous and serous cutaneous glands of two adult specimens of the Phyllobates bicolor frog in order to contribute to understand the mechanisms that facilitate the accumulation of substances in the skin of frogs.

\section{MATERIAL AND METHOD}

Animals. Phyllobates bicolor Duméril and Bibron 1841, has an approximate size of $3.5 \mathrm{~cm}$ long with bright colors partially or completely in the dorsum and an abdomen black, orange or golden. Its habitat is associated with an ecosystem of tropical rain forest or lowland subtropical rain forest (500 and $1.500 \mathrm{mamsl}$ ), mountain forest, wetlands, rivers, streams and waterfalls in the regions of the states of Cauca, Chocó, Risaralda and Valle del Cauca. They are carnivores; their food mostly consists of arthropods such as ants, beetles and caterpillars (Silverstone, 1976). In their cutaneous secretions it is possible to find batrachotoxins, histrionicotoxins and pumiliotoxins (Daly et al., 1987). Two adult specimens of this species were collected on September 25th, 2011 in San Jan del Palmar, Chocó State (Colombia). The frogs were taken to the laboratory, where they were sacrificed by placing them at a temperature below $4^{\circ} \mathrm{C}$ for five minutes.

Histology. A $1 \mathrm{~cm}^{2}$ of skin of the dorsum of the frog was obtained and placed in in buffered Formaldehyde $(100 \mathrm{ml}$ of Formaldehyde at $37 \%, 900 \mathrm{~mL}$ of distilled water, $0.4 \mathrm{~mL}$ of monobasic sodium-phosphate and $0.65 \mathrm{~mL}$ of dibasic sodium-phosphate). After fixation, the samples were dehydrated with alcohol at 70\% (1 immersion), alcohol at $80 \%$ ( 1 immersion), alcohol at $95 \%$ (2 immersions) and alcohol at $100 \%$ (4 immersions); clearing of tissues was done with Xylol (2 immersions) and impregnation with paraffin. After the process of dehydration of skin specimens, the specimens were embedded in Paraplast Xtra ${ }^{\circledR}$ McCormick $\AA$ in order to obtain sections of $4 \mu \mathrm{m}$. The sections were stained with hematoxilin-eosin, PAS and Masson Trichrome. The histological technique corresponds to the protocol of preparation of samples and specimens suggested by García del Moral (1993).

\section{RESULTS}

The histological study was done on tissues, cells and accessory structures that constitute the epidermis and dermis. The covering epithelia, as well and the glandular epithelia and the connective tissues using threes staining techniques, and our findings were subsequently compared to the current descriptions available in the literature.

Epidermis and dermis. The skin of $P$. bicolor consists of an epidermis and dermis. In the sections that were stained with hematoxilin-eosin, the epidermis exhibited a mucous stratified squamous epithelium (non-keratinized) that consists of four to six layers of keratinocytes that can be categorized in three strata, one basal germinative, that contains a monolayer of cylindrical cells with round nuclei central and basophilic, a stratum intermedium, that consists of two to five layers of polygonal cells with oval nuclei, and an apical stratum of cells with flat nuclei (picnotic) slightly basophilic in which it is possible to see in some regions segments that are interrupted by an intense eosinophilic band compatible with keratine, which covers irregularly the stratum intermedium. In between the epidermis, it is possible to see the excretory ducts and stomas of the cutaneous glands formed by three of four round epithelial cells supported by a basement membrane PAS positive and surrounded by myoepithelial cells with flat nuclei (Figs. 1A-C). 


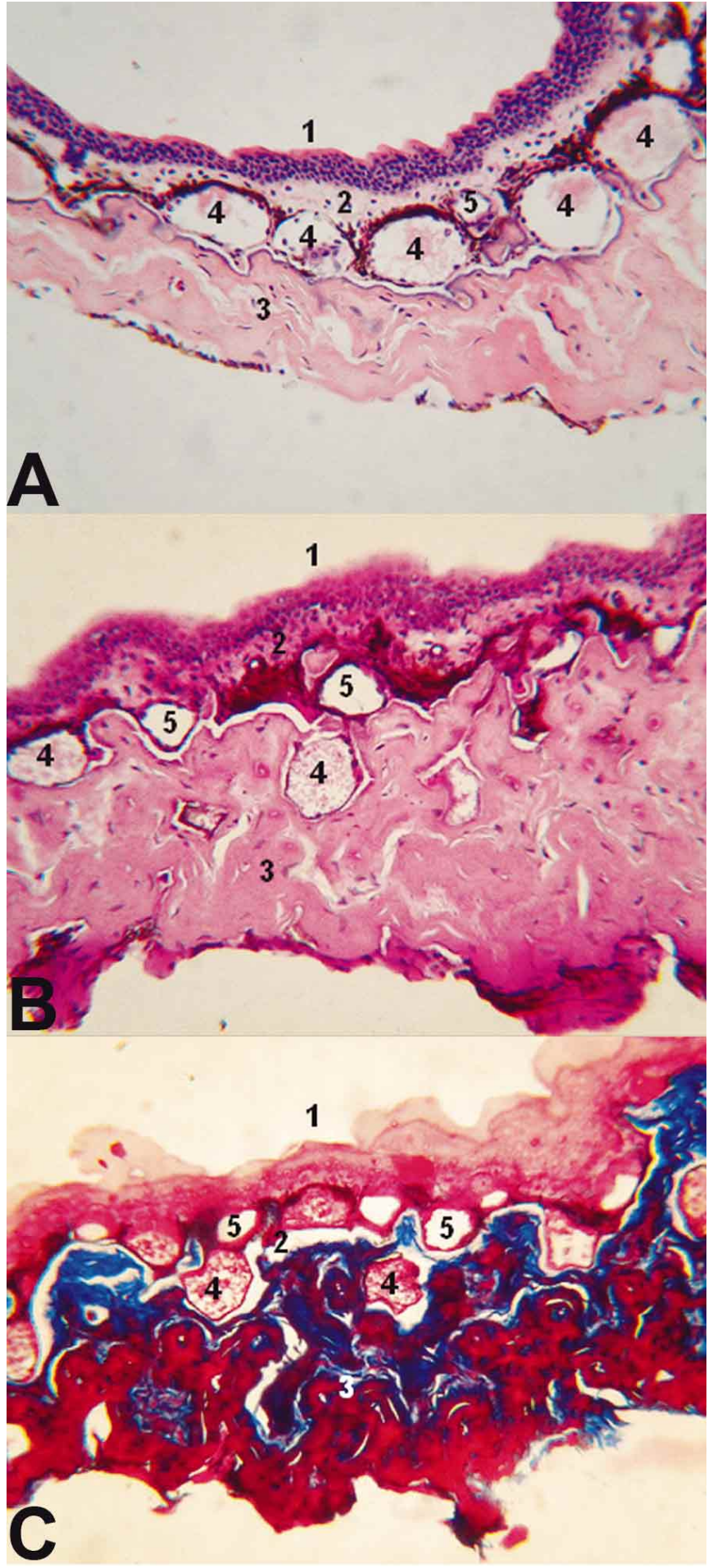

Fig. 1. A. Phyllobates bicolor skin in hematoxylin-eosin stain at $4 X$. Epidermis (1), stratum spongiosum (2), compact stratum (3), serous glands (4), mucous gland (5). B. Phyllobates bicolor skin in PAS stain at $4 X$. Epidermis (1), stratum spongiosum (2), compact stratum (3), serous glands (4), mucous gland (5). C. Phyllobates bicolor skin in Masson trichrome stain at 4X. Epidermis (1), stratum spongiosum (2), compact stratum (3), serous glands (4), mucous gland (5).
In the dermis, two strata were observed, the spongious dermis that consists of loose connective tissue, immediately inferior to the germinal basale strata of the epidermis. This stratum originates from a basement membrane PAS positive (associated to the presence of proteoglycans that bind to periodic acid during the staining process). The basement membrane is interrupted by the cutaneous glands found in between the stratum basal of the epidermis and the spongy dermis. In the loose connective tissue, the extracellular matrix is irregular due to interspersed collagen fibers (clearly visible in the sections that were stained with Masson trichrome), abundant mucous and serous glands are visible were observed and will be described later. We also observed melanin pigment cells or melanophores, myo-epithelial cells and abundant blood vessels. The second stratum is the compact dermis that contains dense irregular connective tissue with abundant collagen fibers organized in wavy segments, oriented parallel to the epidermis. In the interstitium some muscular fibers and blood vessels are also visible. In the sections stained with Masson trichrome, the non-fibrous components of the extracellular matrix is stained with light blue shades, whereas in the fibrous component, the elastic fibers appear light blue and the collagen fibers are dark blue, given its affinity for acid stains due to the large amount of cationic groups of amino acids that form the polypeptide chains. By contrast, in the sections stained with PAS, the fibrous component of the extracellular matrix (elastic and collagen fibers) stain with a deep eosinophilia, while the non-fibrous component (hyaluronic acid) stains show a slight eosinophilia and it is PAS positive due to the presence of carbohydrates in its chemical composition. With the three types of stains, it is possible to observe large and brown pigmentation of melanin associated with the presence of melanophores (deep cromatophores) in the spongy dermis underneath the basement membrane and around the cutaneous glands and in the compact dermis underneath the dense collagen fibers (Figs. 2A and 2B).

Glands as accessory cutaneous structures. In the spongy dermis, immediately below the epithelium, it is possible to see two types of simple alveolar glands, the mucous glands and the serous or granular glands. The mucous glands correspond to round acini found just underneath the epithelium, with limited light by mucocytes, which outside their basement membrane (visible in the sections stained with PAS), are surrounded by myoepithelial cells of elongated nuclei as a contractile sheet known as a myoepithelium and also surrounded by melanophores. In the sections stained with hematoxilin-eosin the mucous acinar cells show an eosinophilic cytoplasm and the nucleus is round, central and basophilic (Fig. 3A). 


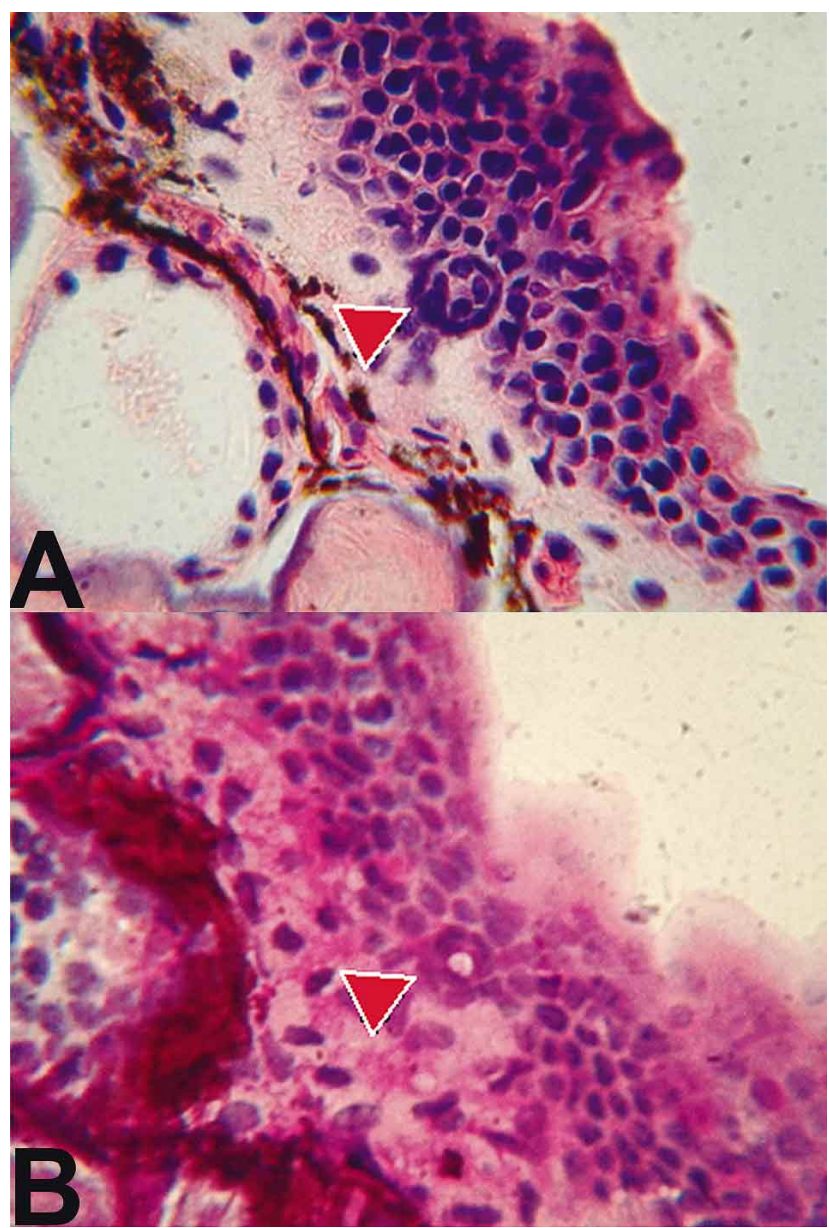

Fig. 2. A. Stoma Phyllobates bicolor skin in hematoxylin-eosin stain. B. Stoma Phyllobates bicolor Skin in PAS stain (10X).

The intense eosinophilic content, visible in the sections stained with PAS in the glandular lumen, reacts with periodic acid. This content is compatible with mucous secretions PAS positive associated with acid non-sulfate mucopolysaccharides, such as epithelial syalomucins and acid sulfated mucopolysaccharides such as epithelial sulfomucines, mucoproteins and mucolipids (García del Moral) (Fig. 3B).

On the other hand, the serous glands are located close to the compact dermis and they are surrounded by thick bundles of collagen fibers that provide support and stability. These glands from a glandular oval compartment, generally larger than the mucous glands and have syncitial walls with special characteristics. They constitute a glandular unit as a polarized syncitium of secretory cells that always contains its secretory products in cytoplasmic granules (this is the origin of their name), and they are released into a wide lumen. As it occurs with mucous glands, around the serous glands a discontinuous layer of myoepithelial cells is observed. This layer is in continuity with the intercalated duct that collects the syncytial content and continues as an intra-epidermal duct as it arrives at the epithelium. This duct is formed by

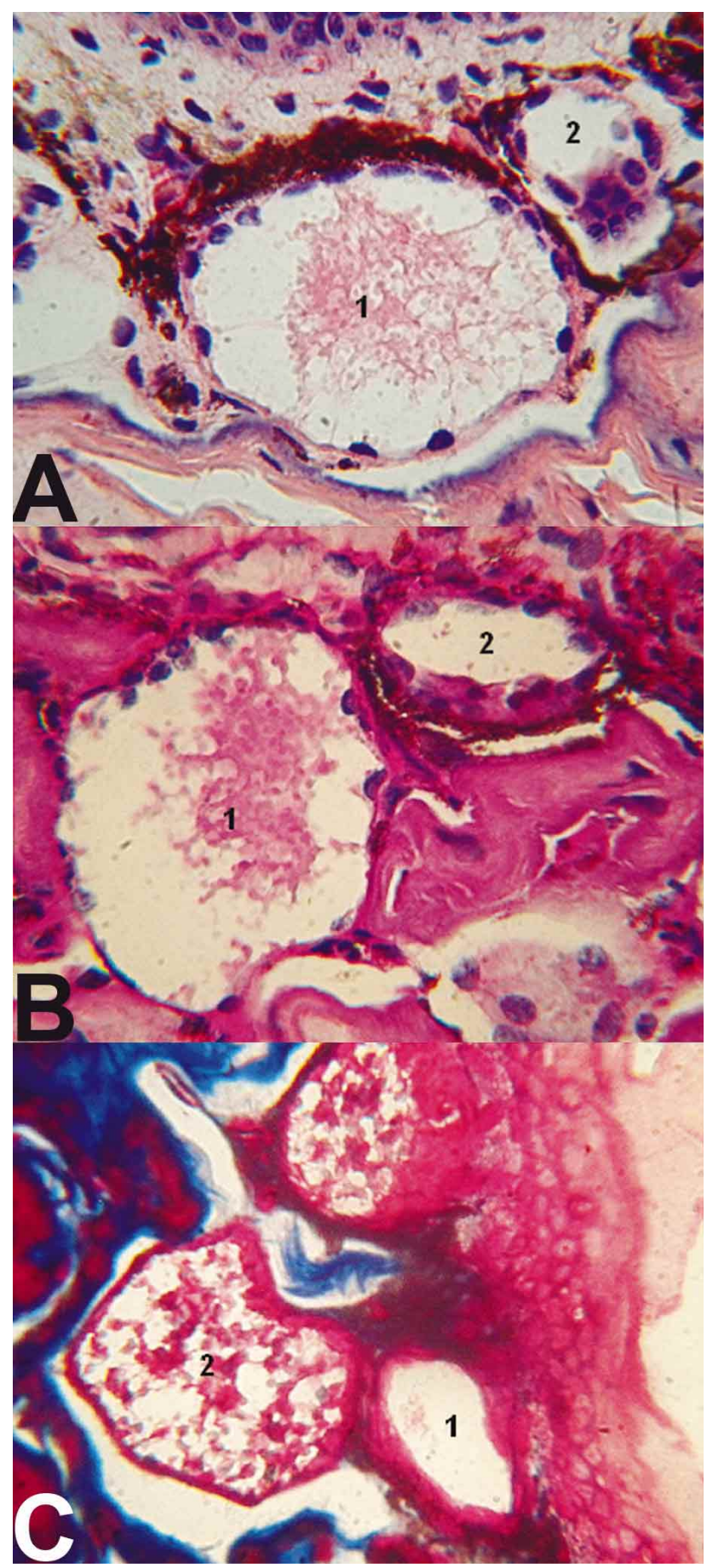

Fig. 3. A. Stratum spongiosum of the Phyllobates bicolor in hematoxylin-eosin stain. Serous gland (1), mucous gland (2). B. Stratum spongiosum of the Phyllobates bicolor in PAS stain. Serous gland (1), mucous gland (2). C. Stratum spongiosum of the Phyllobates bicolor in Masson trichrome stain. Serous gland (1), mucous gland (2) (40X). 
three to four modified epithelial cells, which constitute the stoma. Melanophores that surround the glands in their apical and lateral surface were observed (just below the epithelium, the dermoepithelial junction and also throughout the entire stratum spongiosum). Blood vessels associated to the exocrine function of glands were also visible. In the basal surface, a dense regular connective tissue was observed with abundant collagen fibers (that appear blue in the sections stained with Masson trichrome), and they constitute the compact stratum of the dermis (Fig. 3C).

\section{DISCUSSION}

Stomas. As it was previously described, intercalated ducts originate from the mucous and serous glands, which will continue as intra-epidermal ducts that lead to the epidermal surface through a structure known as a stoma. Noble \& Noble (1994) in the Lithobates pipiens frog, observed modified epithelial cells that surround the intra-epidermal ducts and connect to the epithelial surface through a structure known as a stoma. These cells have a round appearance, and constitute a syncytium in which each one of them is associated with epithelial cells to form the duct itself or the stoma, and this is why they are known as stomal cells.

In the present study, in the sections stained with hematoxilin-eosin, it is possible to see in the epidermis of the frog P. bicolor the same configuration of stomas with three to four stomal cells surrounded by epithelial cells, supported by a basement membrane, as it was observed in the sections stained with PAS. Similarly, myoepithelial cells with flat nuclei around the stomal cells form a discontinuous layer know as a contractile sheath (myoepithelium) (Figs. $2 \mathrm{~A}$ and $2 \mathrm{~B}$ ). As it has been described in the literature, the presence of this type of contractile cells has been associated to the excretory mechanism, including the secretory portion of the mucous and serous glands (syncytium), the intercalated duct and finally the intra-epidermal duct as it reaches the epithelial surface (Angel et al.; Felsemburgh et al.).

Mucous glands. Els \& Henneberg found in a sample of the skin of the frog Lithobates pipiens, that the secretory granules visible in the lumen of the mucous glands were produced by two types of mucous cells. These granules were found to be PAS positive, which was associated to the presence of glycoproteins of acidic nature, rich in hexoses and deoxyhexoses. However, when the modified AB-PAS was used, they found that one type of granules secreted by the principal glands affinity for alcian blue (alcianophilia) (Delgado-Ramírez et al., 2012; Parpinelli et al., 2013), while the other type of granules secreted by the second type of cells did not stain with alcian blue due to the neutral nature of the glycoprotein content (Els \& Henneberg).

In our study, in the lumen of the mucous glands of the frog P. bicolor, in the sections stained with hematoxilineosin and PAS, all the granules appeared to be intensely eosinophilic, which does not allow to draw any conclusion regarding to the acid or basic nature of the content of those granules (Figs. 3A and 3B). However in the sections strained with Masson trichrome, some granules stained blue, because they reacted with the blue dye due to their acid nature. Similarly, some granules with acid nature stained red when they reacted to fuchsine (Fig. 3C). These differences between the different staining techniques correspond to what has been previously described by Els \& Henneberg. They concluded that the secretion of mucous glands correspond to a heterogeneous substance (responsible for maintaining the epidermis moist). This substance is secreted by two different types of cells, the principal cells that are responsible for providing the largest proportion of acid glycoproteins and a second group of cells that provide neutral glycoproteins and sulfated glycosaminoglycans.

Serous glands. In the skin of $P$. bicolor it was found that serous glands are more numerous than the mucous glands, their acinus is larger, the lumen is wider, the cells are flatter, with large and round peripheral nuclei and they contain a secretory syncytium. This corresponds with the description of Neuwirth et al. and Delfino et al. with transmission electron microscopy in skin samples of the same frog species. Based on the hypothesis that frogs of the Dendrobatidae family acquire the alkaloids from their diet, it is possible to think that those substances arrive through the bloodstream to the secretory syncytium and that this structure would help with the transport to the glandular lumen where finally the alkaloids are stored.

Noble \& Noble described the cutaneous glands of Rana pipiens (mucous and alveolar) as an alveolar cavity surrounded by cuboidal epithelial cells, as a monolayer of simple cuboidal epithelium, and in their cytoplasm it is possible to observe secretory granules. The authors also observed that the serous glands are larger in size and in number than the mucous glands, which is confirmed in this description. In our study it was also seen that in some serous glands there is a series of contents that stain indistinctly according to the secreted products and their affinity reaction for each one of the staining techniques that was used. In the sections stained with hematoxilin-eosin it is possible to observe some eosinophilic granules associated with the affinity to basic components. These basic components can correspond to lipophilic alkaloids since these skin samples were taken from frogs recently collected in their natural 
environment. In the sections stained with PAS, the reaction of the periodic acid has affinity for granules PAS positive associated with the presence of epithelial psyalomucins, epithelial sulfomucins, mucoproteins and neutral mucolipids. It is probable that these substances contribute to maintain the alkaloids in the glands and that in addition they prevent their degradation since it has been observed that even after three years of captivity, frogs have only lost around thirty percent of the amount of alkaloid that they had when they were captured (Daly et al., 2005). In the sections stained with Masson trichrome, the alcian blue had affinity for sulfated glycosaminoglycans of acid nature while the basic substances reacted with the basic fuchsin sowing a deep eosinophilia. These findings are very similar to those reported by Felsemburg et al.

\section{CONCLUSIONS}

P. bicolor contains two types of exocrine glands (mucous and serous) located in the spongy dermis, just underneath the epithelium and they are supported by thick bundles of collagen fibers that form the compact dermis. The glands, secrete their products to the outside of the epidermis through an intra-epithelial duct that leads to a stoma formed by three to four modified epithelial cells known as stomal cells.
The mucous and serous glands, as well as the intercalated ducts, excretory ducts and intra-epithelial ducts are surrounded by an interrupted sheath of myoepithelial cells that, upon contraction, collapse the lumina of the acinus and the ducts, facilitating the secretion and release of their contents. The serous glands contain a polarized syncytium of tall cuboidal or cylindrical epithelial cells that are responsible for storing and secreting the glandular contents.

Although the three staining techniques are not specific to determine the composition of the secretions of the mucous and serous glands, it has been possible to determine that both glands have a type of mixed secretion given the affinity (acid and basic) to the different stains by the glandular components, thus the content of the mucous glands tend to be neutral and basic, while those of the serous glands are basic and acid.

\section{ACKNOWLEDGEMENTS}

The authors thank people from San José del Palmar for allowing us to work in their territory. This work was partially supported by a grant given to Helberg AsencioSantofimio from Pontificia Universidad Javeriana Cali, Colombia.

MORENO-GÓMEZ, F.; DUQUE, T.; FIERRO, L.; ARANGO, J.; PECKHAM, X. \& ASENCIO-SANTOFIMIO, H. Descripción histológica de las glándulas cutáneas del Phyllobates bicolor (Anura: Dendrobatidae) usando tres técnicas de tinción. Int. J. Morphol., 32(3):882-888, 2014.

RESUMEN: A la fecha no existe mayor información con respecto a los mecanismos para obtener y almacenar las toxinas cutáneas de ranas de la familia Dendrobatidae. Con el fin de contribuir y entender cómo son almacenadas estas toxinas, realizamos una descripción histológica de las glándulas cutáneas de la especie Phyllobates bicolor. La piel de dos ranas adultas se examinó mediante tres técnicas de tinción histológica (hematoxilina-eosina, PAS y tricrómico de Masson) mediante microscopía óptica convencional. La piel de $P$. bicolor contiene dos tipos de glándulas exocrinas: mucosas y serosas, que vierten sus productos a la superficie epidérmica a través de un conducto intra-epitelial que conduce a un estoma. Las glándulas mucosas, serosas y los conductos intercalados están rodeados por una funda discontinua de células mioepiteliales, las que colapsan el lumen de los acinos y conductos, facilitando la secreción y liberación de su contenido. Las glándulas serosas tienen un sincitio polarizado de células epiteliales columnares cúbicas. Ambas glándulas tienen una secreción mixta, por lo tanto, los contenidos de las glándulas mucosas tienden a ser neutral y basófilas, mientras que los contenidos de las glándulas serosas son basófilas y acidófilas.

PALABRAS CLAVE: Anfibios; Phyllobates bicolor; Tegumento; Epidermis; Dermis; Glándulas mucosas; Glándulas serosas; Defensas químicas; Bioacumulación.

\section{REFERENCES}

Angel, R.; Delfino, G. F. \& Parra, G. J. Ultrastructural patterns of secretory activity in poison cutaneous glands of larval and juvenile Dendrobates auratus (Amphibia, Anura). Toxicon, 41(1):29-39, 2003.
Daly, J. W.; Myers, C. W. \& Whittaker, N. Further classification of skin alkaloids from neotropical poison frogs (Dendrobatidae), with a general survey of toxic/noxious substances in the amphibia. Toxicon, 25(10):1023-95, 1987. 
Daly, J. W. The chemistry of poisons in amphibian skin. Proc. Natl. Acad. Sci. U. S. A., 92(1):9-13, 1995.

Daly, J. W.; Spande, T. F. \& Garrafo, H. M. Alkaloids from amphibian skin: a tabulation of over eight-hundred compounds. J. Nat. Prod., 68(10):1556-75, 2005.

Delgado-Ramírez, J. L.; Aragón, H. J. \& Pérez-Martínez, M. Difference in the Population of Mast Cells of Anal Sac Apocrine Glands of Adult and Senile Dogs. Int. J. Morphol., 30(2):661-5, 2012.

Delfino, G.; Giachi, F.; Nosi, D. \& Malentacchi, C. Serous cutaneous glands in Phyllobates bicolor (Anura: Dendrobatidae): an ontogenetic, ultrastructural study on secretory product biosynthesis and maturation. Copeia, 2010(1):27-37, 2010.

Els, W. J. \& Henneberg, R. Histological features and histochemistry of the mucous glands in ventral skin of the frog, Rana fuscigula. Histol. Histopathol., 5(3):343-8, 1990.

Felsemburgh, F. A.; Carvalho-e-Silva, S. P. \& de Brito-Gitirana, L. Morphological characterization of the anuran integument of the Proceratophrys and Odontophrynus genera (Amphibia, Anuran, Leptodactylidae). Micron, 38(5):439-45, 2007.

Neuwirth, M.; Daly, J. W.; Myers, C. W. \& Tice, L. W. Morphology of the granular secretory glands in skin of poison-dart frogs (Dendrobatidae). Tissue Cell, 11(4):755$71,1979$.

García del Moral, R. Laboratorio de anatomía patológica. Madrid, Interamericana-McGraw-Hill, 1993.

Noble, G. A. \& Noble, E. R. On the histology of frog skin glands. Trans. Am. Microsc. Soc., 63:254-63, 1944.

Parpinelli, A. C.; Lopes, R. A.; Sala, M. A.; Issa, J. P. M. \& Lopes, T. R. V. P. Morphological and Histochemical Study of the Cephalic Glands of Bothrops alternatus (Ophidia, Viperidae). Int. J. Morphol., 31(3):1026-33, 2013.

Saporito, R. A.; Spande, T. F.; Garraffo, H. M. \& Donnelly, M. A. Arthropod alkaloids in poison frogs: a review of the dietary hypothesis. Heterocycles, 79(1):277-97, 2009.

Saporito, R. A.; Donnelly, M. A.; Spande, T. F. \& Garraffo, H. M. A review of chemical ecology in poison frogs. Chemoecology, 22(3):159-68, 2012.

Silverstone, P. A. A revision of the poison-arrow frogs of the genus Phyllobates Bibron in sagra (Family Dendrobatidae). Sci. Bull. Nat. Hist. Mus. Los Angel. Cty., 27:1-53, 1976.

Schöpf, C. Die Konstitution der Salamander-Alkaloide. Experientia, 17(7):285-95, 1961.
Smith, B. P.; Tyler, M. J.; Kaneko, T.; Garraffo, H. M.; Spande, T. F. \& Daly, J. W. Evidence for biosynthesis of pseudophrynamine alkaloids by an Australian myobatrachid frog (pseudophryne) and for sequestration of dietary pumiliotoxins. J. Nat. Prod., 65(4):439-47, 2002.

\author{
Correspondence to: \\ Helberg Asencio-Santofimio \\ Departamento de Ciencias Básicas de la Salud \\ Facultad de Ciencias de la Salud \\ Pontificia Universidad Javeriana \\ Santiago de Cali \\ COLOMBIA
}

Email: hasantofimio@javerianacali.edu.co

Received: 09-02-2014

Accepted: 07-07-2014 